\title{
Periodontal tissue damage in smokers
}

\author{
Hutojo Djajakusuma \\ Department of Oral Medicine \\ Faculty of Dentistry Airlangga University \\ Surabaya - Indonesia
}

\begin{abstract}
Dental plaque is the primary etiological factor in periodontal diseases. However, there are many factors that can modify how an individual periodontal tissue will respond to the accumulation of dental plaque. Among such risk factors, there is increasing evidence that smoking tobacco products alters the expression and rate of progression of periodontal diseases. The aim of this study was to find out the loss of periodontal tissue adhesion in smokers by measuring pocket depth using probe, and by measuring alveolar bone damage using Bone Loss Score (BLS) radiographic methods on teeth 12, 11, 21, 22, 32, 31, 41, 42. Based on T Test statistical analysis, there were significant differences in pocket depth damage of alveolar bone in smokers and non smokers. In conclusion there were increasing pocket depth and alveolar bone damage in smokers.
\end{abstract}

Key words: smoking, periodontal adhesion loss

Correspondence: Hutojo Djajakusuma, c/o: Bagian Oral Medicine, Fakultas Kedokteran Gigi Universitas Airlangga. Jln. Mayjend. Prof. Dr. Moestopo No. 47 Surabaya 60132, Indonesia.

\section{INTRODUCTION}

Smoking has hazardous effect for health. Many studies reveal correlation of smoking to varied diseases such as lung cancer, pharynx and larynx, coronary heart disease, peripheral arteries disorder, ${ }^{1}$ also the correlation of smoking to higher risk of infertility in women ${ }^{2}$ and increased risk of impotency in men. ${ }^{3}$ In dentistry, the effect of smoking to oral changes has been reported in many researches, such as: dry socket occured four times higher at smokers than non-smokers, keratoses, decreased saliva $\mathrm{pH}$, changes of oral micro-floral organism, even malignancy. Various researches of the impact of smoking to periodontal diseases have been reported, among others are smoking caused more severe periodontitis and higher incidence of acute ulcerative gingivitis compared to non-smokers. ${ }^{4}$ Recently showed that passive smokers have 1.5 times higher risk of gum disease than non-smokers. ${ }^{5}$

The world cigarette consumption obviously has increased. In 1996, the developing countries amass 68\% of world cigarette consumption and it rises to $72 \%$ in the year of 2001. ${ }^{6}$ This condition will lead to higher incidence of gingivitis and periodontitis which will ultimately cause fall-out teeth. Furthermore, periodontitis is chronic and destructive. Smokers in general have no knowledge of the damaging process, they come to the dentist long overdue making it more difficult to handle. The aim of, this research at smokers to discover the scale of periodontal tissue damage by measuring clinical periodontal loss using probe 7 and radiography, ${ }^{8}$ so that diagnosis and treatment plan can be determined. As far as the knowledge of the author, no previous research of has been reported. Based on the above background, the problem in this study i.e. is there any difference of periodontal tissue damage in smokers and in non-smokers by clinical and radiographic examination?

\section{MATERIALS AND METHODS}

The tipe of this research was an observational analytical study, and comparative, according to its purpose of comparing periodontal tissue damage in smokers and nonsmokers.

Materials used were: periapical extra-speed film EP 21, fixing solution and developer. Equipments used were: Dental photo X-ray unit, X-ray film holder, caliper, oral mirror, periodontal standard probe, millimeter grid and viewer.

Samples were taken from patients of Airlangga University Faculty of Dentistry consisted of 10 males who had smoked minimal one year ago with an average of 20 cigarettes per day. Non-smoker samples were also taken from patients of Airlangga University Faculty of Dentistry consisted of 10 males who had never smoked. Sample quantity was determined according to sample formula of Sugiarto et al..$^{9}$ To ensure sample's accuracy to research requirements, criteria were added as follows: good general condition (no systemic disorder), aged 20-35, whole anterior teeth were well positioned in dental arch.

Patients were examined to detect clinical periodontal adhesion loss in upper jaw anterior region and lower jaw $12,11,2122,32,31,41,42$ by measuring pocket depth 
using probe from gingival margin until the base of the pocket. Measurement was done at mesial and distal side of each tooth, followed by a radiographic examination using parallel technique. Standard probe technique was used against the proximal side of dental pocket to measure the pocket depth. The periodontal tissue damage was measured according to the percentage of alveolar bone resorption in vertical direction (BLS) in proximal side, based on Adams and Nystrom criteria. ${ }^{10}$

\section{RESULTS}

Research result of 10 smokers and 10 non-smokers towards pocket depth using probe on teeth 12, 11, 21, 22, 32, 31, 41, 42 is seen in figure 1 and 2 .

Figure 1 and 2 showed the average of pocket depth using probe in smokers is bigger than non-smokers on teeth 12 , $11,21,22,32,31,41,42$ from mesial and distal sides.
Figure 3 and 4 showed the average of alveolar bone damage in smokers and non-smokers, measured by BLS radiographic method.

Figure 3 and 4 showed that in smokers, the damage of alveolar bone using BLS based on radiographic examination was higher than non-smokers in region $12,11,21,22,32,31,41,42$, in mesial as well as in distal.

Prior to applying the T Test 2 free sample, a normality test was performed with Kolmogorov-Smirnov. The test result showed all groups had significant value $>0.05$ meaning data was a normal distribution. Further, Levene's test was done to know the homogeneity of two groups variance. If the significant value was $>0.05$, the two groups variance were homogenous. The result of hypotheses test using t 2 free sample produced significant value $\leq 0.05$ meaning there was a significant difference of pocket depth in smokers and non-smokers using probe and using BLS method based on radiographic examination, both on 12 , $11,21,22,31,32,42,41$ region in mesial and distal sides.

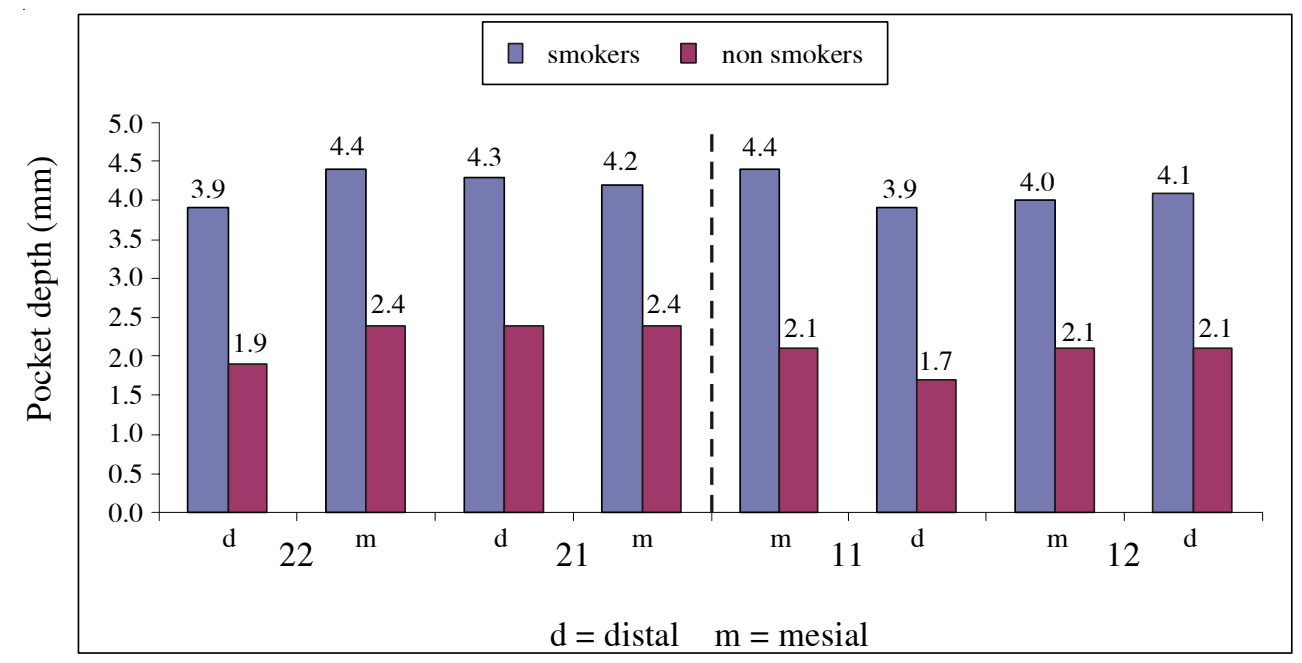

Figure 1. Pocket depth average in smokers and non-smokers using probe on upper jaw (mm).

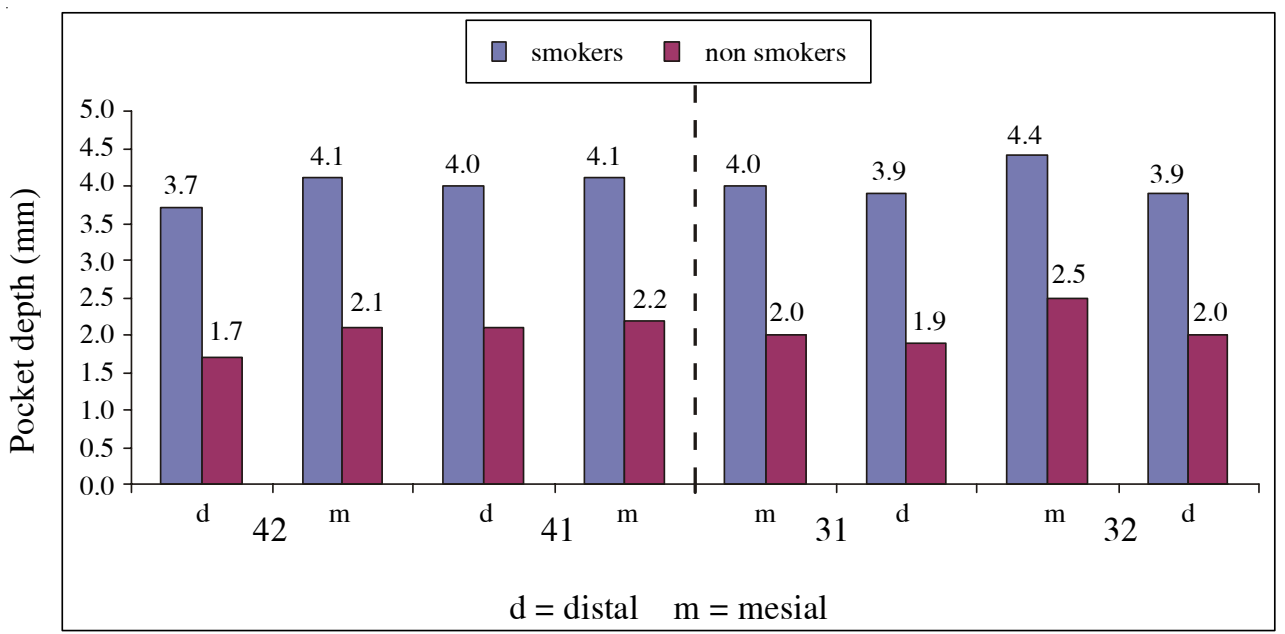

Figure 2. Pocket depth average in smokers and non-smokers using probe on lower jaw (mm). 


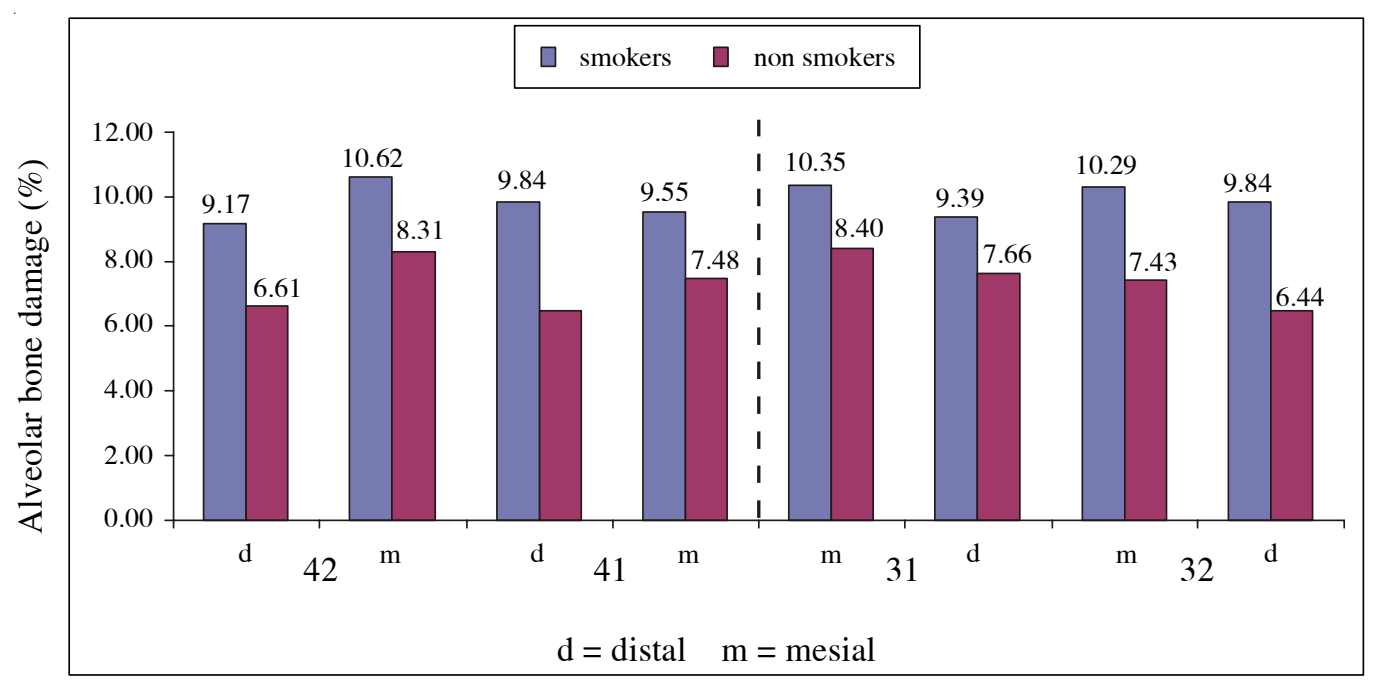

Figure 3. The average of alveolar bone damage in smokers and non-smokers using BLS method (\%) based on upper jaw radiographic examination.

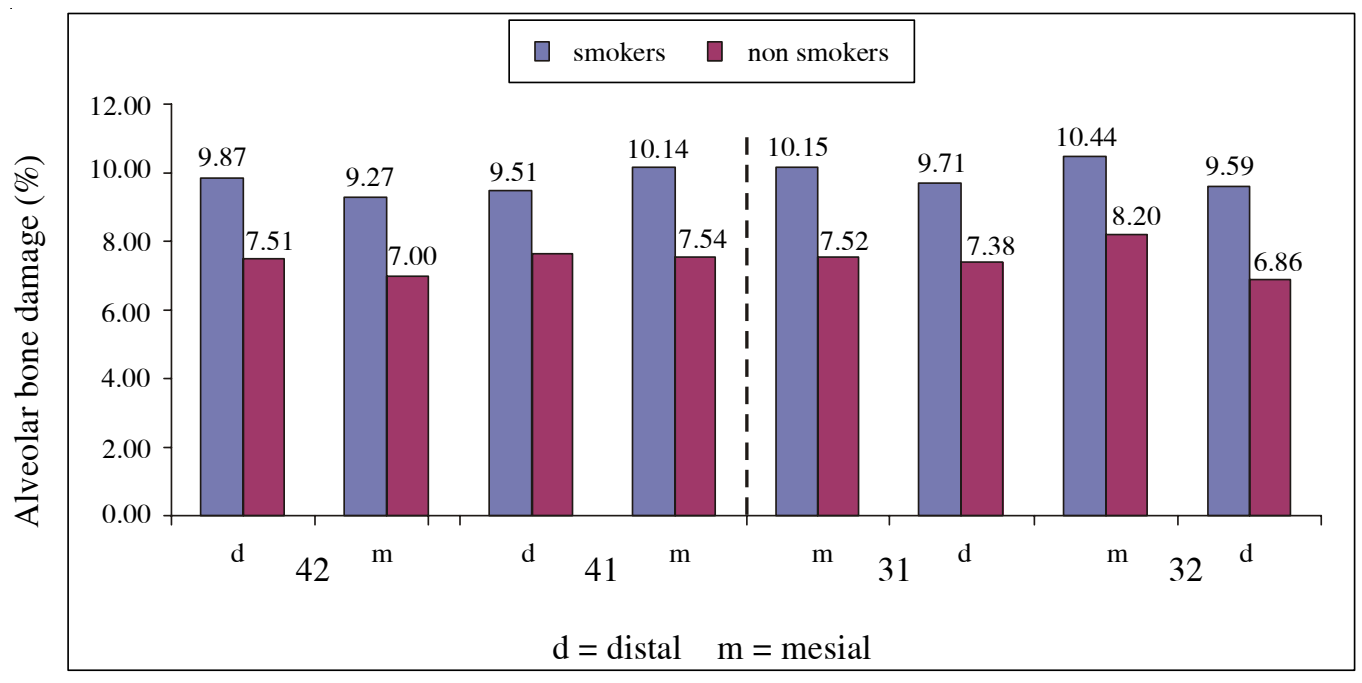

Figure 4. The average of alveolar bone damage in smokers and non-smokers using BLS method (\%) based on lower jaw radiographic examination.

\section{DISCUSSION}

\section{Test result of clinical periodontal adhesion loss}

Periodontal tissue damaged is most often tested by measuring the loss of clinical periodontal adhesion and by radiographic examination. ${ }^{11-12}$ Both measuring methods are easy, fast, inexpensive and painless. Periodontal adhesion loss is measuring by pocket depth i.e. the distance of gingival edge until the base of penetration of the probe tip. The study shows that the average of pocket depth in smokers is bigger than non-smokers in teeth $12,11,21$, $22,31,32,42,41$ in mesial and distal sides. This condition shows that the pocket depth in smokers is bigger than in non-smokers.
Statistical test of the T 2 free sample presents a significant value $<0.05$ meaning there is a significant difference of smokers and non-smokers pocket depth using probe method in $12,11,21,22,31,32,42,41$ in mesial and distal. This is in accordance with several studies stating smokers are prone to gingivitis and periodontitis than non-smokers. ${ }^{13,14}$ In this condition, periodontal pocket forming and alveolar bone damage can be found. ${ }^{15}$ The finding is supported by Akhmad et al. ${ }^{16}$ who stated that the prevalence of smoking habit is more dominant as the cause of the prevalence of periodontal diseases. Presumably, it is triggered by smoker's condition, where a potential variation change of reduction-oxidation at gingival area takes place indicating the presence of 
anaerobic microorganism. The decline of reductionoxidation will increase anaerobic plaque bacteria. ${ }^{4}$ In addition, tobacco influence oral cavity immune system and smoking decreases oral cellular immunity by way of decreasing chemotactical response, phagocytic of leukocyte and it causes vasoconstriction which in the end it will decrease tissue immune response. ${ }^{17}$ As the result of an infection, epithelia adhesion proliferate along dental root's surface towards the apical side, producing the lessening of desmosome adhesion, causing the detachment of epithelium surface from dental root surface, thus creating a deeper sulcus base. ${ }^{18}$ Yet, several studies state that this manner can not measure the size of adhesion loss accurately, because the measurement initial pole is the edge of gingival which are unsteady. The suggested method is transgingival probing (sounding depth probing). ${ }^{19}$ The clinical adhesion loss and the transgingival probing have a similar measuring method, except for pressure difference, more or less by 100 gr. The pressure difference will produce a different result of measurement i.e. the clinical adhesion loss measurement describes the pocket base, while the transgingival probing measurement describes the base of alveolar bone damage. 7,11,20 The examination is rarely performed due to its unpleasantness.

\section{Test result of alveolar bone damage}

The dentistry world has recognized the importance of dental radiography for diagnoses tool, dental therapy plan, and treatment result assessment. The quality of radiography depends on several factors, among others are radiography technique and film processing. ${ }^{8}$ The most sophisticated dental X-ray unit has not guarantee to produce a good radiograph, if it lacks suitable radiography technique. Wei ${ }^{21}$ said, in order to make a radiography of dental anterior upper and lower jaws, for intra oral radiography, the method-ofchoice is periapical technique because the picture is more accurate and the distortion is smaller should the film placing is correct.

Test result of alveolar bone damage shows that the average of alveolar bone damage in smokers is greater than in non-smokers in 12, 11, 22, 32, 31, 41, and 42 in mesial and distal sides. The result is supported by the statistical t 2 free sample test, with a significant value $\leq 0.05$ pointing that there is a significant difference of alveolar bone damage between smokers and non-smokers using BLS method of radiographic examination in region $12,11,21,22,32,31$, 41, 42 in mesial and distal sides.

The statement is in accordance with previous studies stating that a radiographic examination exposes an increase in alveolar bone resorption paralleled to an increase of tobacco use, and the prevalence of periodontal disease and alveolar bone resorption is higher in smokers compared to non-smokers. Also from an observation and assessment to bone density, smokers show bigger resorption than in non-smokers, and it also reveals a correlation of smoking with more severe periodontitis, that is the incidence of periodontitis is faster in smokers than in non-smokers. ${ }^{17}$
The increase of alveolar bone damage can be the result of increased infection ${ }^{17}$ and infection will result in faster bone alveolaris resorption so that it causes the resorption and the height of alveolar bone will be shortened. ${ }^{22}$

A radiograph of an alveolar bone damage demonstrates a crest alveolar resorption picture. Alveolar bone density declines more than $3 \mathrm{~mm}$ starting from the tip of the bone, email margin and cementum. ${ }^{8}$ A radiographic examination using parallel technique, will bring about the result of correct radiograph. A radiographic examination applying parallel technique will produce a better, more accurate measurement towards the height of alveolar bone tissue, in relation to cement enamel junction. ${ }^{23}$ In addition, using BLS method will enable us to find out the exact percentage of alveolar bone damage, so that the treatment will be precise.

Based on this experiment exposing the pocket depth and alveolar bone damage in smokers compared to non-smokers, it is suggested to dentists as oral and dental hygiene personnel to play an important role promoting and stressing community for awareness of the danger of smoking in general and oral health in particular. By knowing the percentage of alveolar bone damage using BLS method with radiographic examination, a definite treatment plan can be executed correctly.

There is no preliminary study in this writing, therefore to clarify whether the periodontal damage happened because of smoking or prior to smoking, it is strongly suggested for other researchers to do supportive examinations preceding the study.

\section{REFERENCES}

1. WHO. Tobacco and Health Impact. Available at: http://www.who.int/ tobacco/health_impact/en/. Accessed May 13, 2006.

2. Hull, et al . Delayed conception and active and passive smoking. The Avon longitudinal Study of Pregnancy and Childhood Study Team. Fertil Steril. 2000 Oct; 74(4):725-33. Available at: http://www.ncbi.nim.nih.gov/entrez/query.fogi?cmd = Retrieve \& db $\equiv$ PubMed\&dopt-Citation\&list uida $=11020514$. Accessed May 13, 2006.

3. Tengs To, Osgood ND. The link between smoking and impotance: two decades of evidence. Prev Med 2001 Jun; 32(6):447-52. Available at: http://www.ncbi.nim.nih.gov/entrez/query.fcgi? cmd $=$ Retrieve $\& \mathrm{db}=$ PubMed $\&$ dopt $=$ Citation\&list_uids $=11394947$. Accessed May 13, 2006.

4. Ruslan G. Efek merokok terhadap rongga mulut. Available at: File://G:/Cermin\%20 Dunia\%20 Kedokteran.htm. Accessed March 28, 2006.

5. Jaga-jaga. Perokok pasif dapat menderita gangguan gusi. Availabel at: http://www.jaga-jaga.com/an 1 hatiyook.php? ida =236. Accessed March 28, 2006.

6. Yurekli, Bayer. Bank dunia 2002. Available at: http:// www1.worldbank.org/tobacco/pdt/indonesian.pdf. Accessed May 13, 2006.

7. Theil EM, Heaney TG. The validity of periodontal probing as method of measuring loss pf attachment. J Clin Periodontol $1991 ; 18: 648-53$

8. White SC, Pharoah MJ. Oral radiology: Principles and interpretation. $5^{\text {th }}$ ed. New Delhi: El Sevier; 2004. p. 321.

9. Sugiarto, Siagian D, Sunaryanto LT, Oetomo DS. Teknik sampling. Cetakan kedua. Jakarta: Penerbit PT Gramedia Pustaka Utama; 2003. h. 32. 
10. Adams RA, Nystrom GP. Periodontitis severity index. Journal of Periodontology 1986; 57: 177.

11. Pihlstrom BL. Measurement of attachment level in clinical trials: probing methods. J Periodontol 1992; 63:1072-77.

12. Kelly GP, Cain RJ, Knowles JW, Nissle RR, Burgett FG, Shick RA, Ramfjord SP. Radiographs in clinical periodontal trial. J Periodontol $1975 ; 46: 381-86$.

13. Bastian, Waite IM. Effects of tobacco smoking on plaque development and gingivitis. J Periodontol 1978; 49:480-82

14. Hidalgo RF. Smoking and Periodontal Disease. J Periodontol 1986; 57:61724.

15. Carranza FA. Glickman's clinical periodontology. $7^{\text {th }}$ ed Philadelphia, London, Toronto, Montreal, Sydey, Tokyo: WB Saunders Company; 1990. p. 51-61, 234-49, 513-7.

16. Akhmad, Hasan H, Syamsuddin. Available at: http://litbang.kaltim.go.id/ HASIL\%20PENELITIAN BIDANG\%20KEMASYARAKATAN/ SEKTOR\%20SOSIAL \% 20POLITIK/ABSTR A K \% 20 SEKTOR\%SOSIAL\%20POLITIK\%203.10.12.4.html/. Accessed May $15,2006$.
17. The Colgate Periodontal Education Program. Smoking and periodontal disease. Available at: http://www.adelaide.edu.au/spdent/ dperu/cpep/smoking.htm. Accessed May 15, 2006.

18. Stahl SS. Speculations on periodontal attachment loss. J Clin Periodontol 1986; 8:98-106.

19. Yehouda AB, Machtei EE. Sounding depth measurement: a method for evaluating various surgical technique. J Periodontol 1991; 62:565-69.

20. Velden VDU. Probing force and the relationship of the probe tip to the periodontl tissue. J Clin Periodontol 1979; 16:106-14.

21. Wei SHY. Pediatric dentistry: Total patient care. Philadelphia: Lea and Febiger; 1998. p. 115-38.

22. Halazonetis TD, Haffajee AD, Sockransky SS. Relatioship of clinical parameters to attachment loss in subsets of subjects with destructive periodontal disease. J Clin Periodontol 1989; 16:563-8.

23. The Colgate Periodontal Education Program. Radiography and Periodontal Diagnosis. http://www.adelaide.edu.au/spdent/dperu/ cpep/radio.htm. Accessed May 15, 2006. 